\title{
Lípóprótein(a) og áhrif pess á hjartasjúkdóma
}

Norðmaðurinn Kåre Berg uppgötvaði lípóprótein „litla“ a (Lp(a)) árið 1963 og tengdi pað við kransæðasjúkdóm. ${ }^{1}$ Síðan hefur verið staðfest að Lp(a) er sjálfstæður áhættupáttur fyrir kransæðasjúkdóm, skylda æðasjúkdóma og ósæðarlokuprengsl. ${ }^{2}$ Lp(a) hefur fylgni við hjartabilun sem skýrist líklega af áhrifum pess á kransæðasjúkdóm.

Prátt fyrir að $L p(a)$ hafi verið rannsakað í hálfa öld er hlutverk pess ópekkt og ekki vitað fyrir víst hvernig pað veldur kransæðasjúkdómi. ${ }^{3}$ Lp(a) er gert úr lágpéttni lípópróteini og apólípóprótein(a) (apo(a)) sem tengjast með dísúlfíð-bandi. Sameindin er búin til í lifrinni en pað er óljóst hvernig hún er fjarlægð úr blóði og engum sértækum Lp(a)-viðtaka hefur verið lýst.

Lp(a) er óvenjulegt að pví leyti að á milli einstaklinga er mikill breytileiki í bæði stærð sameindarinnar og styrk í blóði. Sterk öfug fylgni er á milli pessara eiginleika sem báðir eru að mestu ákvarðaðir af erfðaefninu, pannig að einstaklingar með stór Lp(a) eru að jafnaði með lítinn styrk Lp(a) í blóði og öfugt. Рað hefur verið umdeilt hvor eiginleiki Lp(a)sameindarinnar stuðli að myndun kransæðasjúkdóms eða hvort hvor um sig hafi sjálfstæð áhrif.

Við hjá Íslenskri erfðagreiningu ásamt samstarfsmönnum okkar gerðum nýlega yfirgripsmikla rannsókn sem varpar ljósi á pessa og fleiri spurningar um Lp(a). ${ }^{2}$ Par nýttum við Lp(a)-mælingar okkar á 12.000 Íslendingum. Par sem bæði stærð og styrkur Lp(a) ákvarðast af erfðum gátum við með pví að bera saman Lp(a) og erfðaefni pessara 12.000 Íslendinga áætlað stærð og styrk Lp(a) fyrir 130.000 Íslendinga til viðbótar með fyrirliggjandi upplýsingum um bæði arfgerð og svipgerð. Við sýndum með óyggjandi hætti að styrkur Lp(a) skýrir að fullu tengsl Lp(a) við áhættu á hjartasjúkdómum og að stærðin bæti par engu við. Við áhættumat (og mat á virkni lyfjameðferðar) nægir pví að mæla styrk Lp(a) í blóði.

Í íslenska pýðinu var styrkur Lp(a) á bilinu núll til 600 nanómolar (nM) en dreifingin var óvenjuleg eins og lýst hefur verið fyrir önnur pýði par sem flestir voru með lítið $\mathrm{Lp}(\mathrm{a})$ og miðgildið eingöngu $14 \mathrm{nM}$. Rúm 20\% Íslendinganna í rannsókninni voru með meira Lp(a) en 50 nM. Áhættan á hjartasjúkdómum var í beinu hlutfalli við styrk Lp(a) og jókst frá líkindahlutfallinu 1,11 við $50 \mathrm{nM}$, miðað við meðaláhættu Íslendinga, í 1,50 við 150 nM, og 2,01 við 250 $\mathrm{nM}$.

Við staðfestum að Lp(a) hefur áhrif á kransæðasjúkdóm og skylda æðasjúkdóma, ósæðarlokuprengsl, hjartabilun og ævilengd. Við sáum hins vegar ekki tengsl við bláæðasega eða nýrnasjúkdóma.

Par sem erfðir ákvarða nánast að fullu styrk Lp(a) í blóði er ekki hægt að hafa áhrif á pennan áhættupátt með lífsstílsbreytingum og í dag eru engin lyf sampykkt til lækkunar á Lp(a). Pó er vitað að til dæmis níasín og lyf sem hamla PCSK9 geta lækkað Lp(a) um 30\% en til að hafa merkjanleg áhrif á hjartasjúkdóma parf líklega að lækka styrk Lp(a) mun meira en pað. Mörg lyfjafyrirtæki eru nú að próa lyf sem miða að pví að lækka styrk Lp(a) í blóði um 80\%.

En eru fylgikvillar við að lækka Lp(a) í blóði svona mikið? Við sýndum í okkar rannsókn að einstaklingar með ekkert eða mjög lítið Lp(a) í blóði $(<3,5$ $\mathrm{nM}$ ) hafa auknar líkur á sykursýki (líkindahlutfall 1,16-1,45) en við greindum ekki fylgni við aðra sjúkdóma og einstaklingar sem eru án Lp(a) virðast að öðru leyti heilbrigðir. Pess ber að geta að prátt fyrir auknar líkur á sykursýki eru einstaklingar með lítið Lp(a) í blóði (<3,5 nM) ekki með auknar líkur á hjartasjúkdómum.

Evrópsku hjartalækningasamtökin ráðleggja að mæla Lp(a) hjá fullorðnum til að finna pá sem hafa mjög há Lp(a) gildi (>430 nM) en peir gætu haft sömu áhættu á æðakölkunarsjúkdómi og einstaklingar með arfblendna arfgenga kólesterólhækkun. ${ }^{4}$ Pá getur Lp(a)-gildi haft áhrif á áhættumat og ráðleggingar um forvarnir, sérstaklega hjá peim sem eru metnir með meðalmikla áhættu á æðasjúkdómi.

Prátt fyrir framfarir í forvörnum og meðferð má enn rekja um 40\% dauðsfalla til hjarta- og æðasjúkdóma. Рað var niðurstaða rannsóknar okkar að með pví að lækka Lp(a) í blóði hjá peim sem eru með hærra gildi en $50 \mathrm{nM}$ (sem eru rúm 20\% Íslendinga) niður í 14 nM megi draga marktækt úr áhættu á hjarta- og æðasjúkdómum án pessa að auka líkur á sykursýki. Рað verður spennandi að sjá hvort pau lyf sem lækka Lp(a) sem eru nú í próun munu standa undir væntingum.

\section{Heimildir}

1. Berg K, Dahlén G, Frick MH. Lp(a) lipoprotein and pre-beta1-lipoprotein in patients with coronary heart disease. Clin Genet 1974; 6: 230-5.

2. Gudbjartsson DF, Thorgeirsson G, Sulem P, Helgadottir A, Gylfason A, Saemundsdottir J, et al. Lipoprotein(a) Concentration and Risks of Cardiovascular Disease and Diabetes. J Am Coll Cardiol 2019; 74: 298294.

3. Tsimikas S. A Test in Context: Lipoprotein(a): Diagnosis, Prognosis, Controversies, and Emerging Therapies. J Am Coll Cardiol 2017; 69; 692-711.

4. Mach F, Baigent C, Catapano AL, Koskinas KC, Casula M, Badimon L, et al. $2019 \mathrm{ESC} / \mathrm{EAS}$ Guidelines for the management of dyslipidaemias: lipid modification to reduce cardiovascular risk. Eur Heart J 2019; 41: $111-88$.

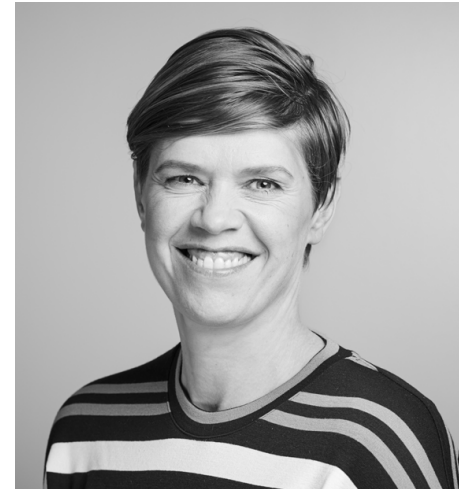

\section{Hilma Hólm}

hjartalæknir, yfirmaður hjartarannsókna hjá Íslenskri erfðagreiningu

Hilma.Holm@decode.is
Lipoprotein(a) and risk of cardiovascular disease

\section{Hilma Hólm MD, PhD} cardiologist, head of cardiovascular research at deCODE genetics / Amgen, Inc. 